\title{
ZIMOWA SŁUŻBA ŻOŁNIERZY WOJSKA POLSKIEGO NA LITWIE I ŁOTWIE NA PRZEŁOMIE 1919/1920 R.
}

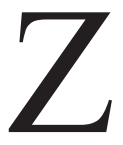

ima nie jest najlepszym czasem do prowadzenia operacji wojskowych, jednak podejmowane one były wyjątkowo - gdy wymagała tego sytuacja polityczna, strategiczna czy zawarte umowy i sojusze. Do takich zaliczyć należy konieczność ochrony linii demarkacyjnej rozdzielającej wojska polskie i litewskie na przełomie 1919 i 1920 r. Linia wytyczona została w związku z pogłębiającym się konfliktem między Polską a Litwą. Jego źródłem były aspiracje niepodległościowe Litwy, które odżyły jeszcze w latach I wojny światowej. Litwini wiązali swą przyszłość z Niemcami, ale plan ten okazał się nierealny po klęsce państw centralnych. Sprawa niepodległości Litwy stała w sprzeczności z planami polskiej dyplomacji, która nie brała pod uwagę całkowitej samodzielności i odrębności tego kraju. Według koncepcji polskiej, Litwa mogła odbudować swą państwowość jedynie jako część odrodzonej Rzeczypospolitej z prawem do własnej autonomii, zachowania języka i kultury, ale związana z Polską umowami regulującymi wspólną politykę gospodarczą i wojskową. Dodatkowo Polacy propagowali nieco upokarzającą tezę, że Litwini byli zawsze cywilizacyjnie i kulturowo zdominowani przez Polaków, gdyż stanowili słabą narodowość, niezdolną do stworzenia i utrzymania niezawisłego państwa.

Głównym przedmiotem sporu, który na lata zaważył na stosunkach polsko-litewskich i stanowił motyw wzajemnych, złych stosunków między obu państwami, było Wilno. Roszczenia do tego miasta zgłaszały obie strony. Krajowa Rada Litwy, zwana Tarybą, ustanowiła 2 listopada 1918 r. Wilno stolicą niepodległego państwa litewskiego, stojąc na stanowisku, że miasto to jest dla Litwinów symbolem ciągłości historycznej i tożsamości Litwy. Z kolei Polska podtrzymywała swoje prawa, wskazując na polski charakter miasta, na jego rolę w rozwoju polskiej kultury 
i nauki oraz na znaczny odsetek mieszkańców narodowości polskiej. Mimo toczących się polsko-litewskich rozmów w sprawie uznania niepodległości Litwy i przynależności Wilna, stosunki między obu państwami były trudne. Relacje te pogorszyły się jeszcze bardziej, gdy Józef Piłsudski podjął decyzję o zbrojnym rozstrzygnięciu przyszłości miasta. Wkroczenie do Wilna wojsk gen. Lucjana Żeligowskiego 19 kwietnia 1919 r. spotkało się z negatywną reakcją państw zachodnich oraz pogorszyło i tak już złe stosunki polsko-litewskie. Mimo to, prowadzone były rozmowy dyplomatyczne, które jednak nie zdołały wpłynąć na zmianę zaistniałej sytuacji ${ }^{1}$. Co więcej, zajęcie Wilna przez Polaków zwiększyło ich obecność na terenach Wileńszczyzny, aż w końcu 24 kwietnia 1919 r. doszło do bezpośredniego spotkania wojsk polskich i litewskich - na szczęście niezakończonego rozlewem krwi. Jednak sytuację w tym regionie należało w miarę szybko unormować, a przede wszystkim rozdzielić wojska polskie i litewskie. W tym celu podjęte zostały działania dyplomatyczne m.in. z udziałem Polaków i Litwinów, które miały wytyczyć linię rozgraniczającą wojska obu stron. Ponieważ przebiegała ona przez sporne terytoria i naruszała roszczenia obu zwaśnionych państw, kolejne propozycje były odrzucane. W czasie, gdy podejmowane były próby wytyczenia linii demarkacyjnej, polskie oddziały przeprowadzały wypady na terytorium litewskie na głębokość $20-30 \mathrm{~km}$, wywierając presję na stacjonujące tam oddziały, by te opuściły zajmowane tereny, jak miało to miejsce np. 4 lipca 1919 r. w miasteczku Jewie na Wileńszczyźnie². Na liczne skargi Litwinów odpowiedział sztab wojsk alianckich marszałka Ferdynanda Focha, który podjął kolejną próbę wytyczenia linii demarkacyjnej. Jej kształt został ostatecznie zatwierdzony 26 lipca 1919 r. przez Radę Najwyższą Ententy. Zwana odtąd linią Focha, rozdzieliła terytoria Litwy i Polski, pozostawiając po stronie polskiej takie miasta, jak np. Wilno, Troki, Orany, Sejny i Puńsk. Po stronie litewskiej pozostały utworzone wcześniej polskie posterunki w Szyrwintach i w Mejszagole, które po wytyczeniu linii nie zostały wycofane na wschód. Prawo do tego pasa ziemi o szerokości około 6-7 km nieformalnie zostało przyznane Polsce ${ }^{3}$.

Oddziały WP rozmieszczono wzdłuż całej linii demarkacyjnej. Stacjonowali tu m.in. żołnierze II batalionu łódzkiego 28 pułk Strzelców Kaniowksich (pSK) ze składu 10 Dywizji Piechoty. Na Litwę przybyli na przełomie września i października 1919 r., po zakończeniu kampanii wołyńskiej i zostali rozmieszczeni

${ }^{1}$ Vide: P. Łossowski, Po tej i tamtej stronie Niemna. Stosunki polsko-litewskie 1883-1939, Warszawa 1985; W.B. ŁACH, Konflikt polsko-litewski o Sejneńszczyznę w latach 1919-1920, [w:] Kresy, granice, pogranicza w historii wojskowej, red. A. Olejko, J. Ślipiec, P. Korzeniowski, K. MroczKOwski, Oświęcim 2014, s. 271-281; A.A. Žulys, Polska w polityce zagranicznej Litwy w latach 1938-1939. Studium z historii dyplomacji, Gdańsk 2015; Z. KraJewski, Polacy w Republice Litewskiej 1918-1940, Lublin 2007.

${ }^{2}$ P. Łossowski, op. cit., s. 108-109.

3 Ibidem, s. 109-110. 
m.in. w okolicach Nowych Trok i Landwarowa, w Owancie i Szyrwintach ${ }^{4}$. Pełnili tu służbę garnizonową i patrolową. Do ich obowiązków należała kontrola ruchu granicznego, zwalczanie przemytu i prób nielegalnego przekraczania linii demarkacyjnej, zarówno od strony Litwy, jak i Polski. Służba przebiegała w warunkach wręcz pokojowych, w czasie której notowano jedynie drobne incydenty graniczne, trwające do połowy marca $1920 \mathrm{r}$.

Mimo pozorów spokoju, najtrudniejszym czasem okazały się miesiące zimowe. Śnieżna i mroźna aura dała o sobie znać już w listopadzie 1919 r. W kolejnych tygodniach śnieg i niskie temperatury stały się źródłem wielu problemów i niedogodności w codziennej służbie. Do tego dodać należy trudne warunki bytowe, braki w wyżywieniu oraz wyposażeniu w zimowy ekwipunek, głównie w płaszcze i obuwie. Wystarczy wspomnieć, że wielu ochotników, którzy wymaszerowali z Łodzi, bardzo często nie posiadało odpowiedniego okrycia wierzchniego, dostosowanego do tak ostrego klimatu, jaki wówczas panował już na północno-wschodnich terenach Wileńszczyzny. Z kolei szczupły budżet armii nie pozwalał na szybkie uzupełnienie braków, zwłaszcza w zakresie jakże potrzebnego żołnierzom umundurowania zimowego. Często przychodziło im pełnić służbę patrolową w samych letnich mundurach, bez płaszczy zimowych i ciepłych nakryć głowy ${ }^{5}$. Stąd odpowiednie zaopatrzenie stało się istotnym problemem w życiu codziennym żołnierzy. Przez cały okres służby dowódcy starali się zminimalizować skutki chłodu i występujących niedostatków. W rozkazach dowódcy 28 pSK często odnaleźć można rady, jak chronić się przed mrozem, by zachować zdrowie oraz dbać o buty, gdyż o nowe było bardzo trudno. Dowództwo zalecało m.in.:

1. Przywykanie do zimna (ćwiczenia na wolnym powietrzu z początku krótkie stopniowo przedłużać). Posterunkom zaleca się być w ruchu 2. Obfite smarowanie tłuszczem obuwia (rozgrzany tłuszcz wołowy lub karabinowy) 3. Troskliwe pielęgnowanie pocących się nóg. Natłuszczanie rąk, uszów, policzków i nosa 4. Owijać nogi lub palce u nóg papierem (na skarpety) 5. Owinąć słomą lub wojłokiem ${ }^{6}$, 6. Szybkie ruchy, 7. Silne machanie rękoma lub nogami, 8. Tarcie uszów, nosa i policzków, 9. Gorące napoje, jak kawa, herbata, 10. Unikać alkoholu?7.

Te założenia, oczywiste dla wielu ludzi, i proste do wykonania sposoby na walkę z zimnem były wówczas cenną wskazówką dla prostych żołnierzy. Nie dla wszystkich zasady higieny były czymś znanym, zaś służba wojskowa stanowiła

\footnotetext{
${ }^{4}$ Obecnie miejscowości te należą do Litwy.

${ }^{5}$ Muzeum Tradycji Niepodległościowych w Łodzi (dalej: MTN/Ł), Ikonografia, I-7280/17 - Żołnierze II batalionu na placówce w Owancie, 1919 r.

${ }^{6}$ Wojłok - filc gorszego gatunku produkowany z wełny odpadowej i sierści.

7 Centralne Archiwum Wojskowe w Wojskowym Biurze Historycznym (dalej: CAW-WBH), 28 Pułk Piechoty, sygn. I.320.28.4, Rozkaz nr 300 na dzień 4 XI 1919 r. wydany w Landwarowie 3 XI 1919 r., brak paginy.
} 
okazję do zmiany ich dotychczasowych nawyków. Powyższe zalecenia dotyczyły wszystkich żołnierzy, a szczególnie pełniących służbę wartowniczą. Surowe warunki klimatyczne wymusiły także zmianę dotychczasowego rozkładu wart, które na posterunkach zewnętrznych zmieniane były co godzinę, a w nocy nawet co pół godziny ${ }^{8}$. Dlatego trudno się dziwić, że dowódca pułku poświęcił tyle miejsca na wskazówki i rady, gdyż niskie temperatury i nie najlepsze warunki sanitarne na kwaterach były źródłem licznych w tym czasie przypadków zachorowań. Mimo pogadanek i instrukcji na temat ochrony przed mrozem ludzi i ekwipun$\mathrm{ku}$ - wprowadzanie różnych zaleceń nie było proste, zaś prawie każdego dnia kilku żołnierzy odsyłanych było do szpitala. Lekarz pułkowy meldował o wzrastającej liczbie chorych, a ich powodem były w głównej mierze braki ciepłego ubrania, bielizny i koców.

Dostarczenie ciepłego umundurowania należało do stałych trosk dowódcy pułku, co było niezmiernie trudne, gdyż szczupłe środki finansowe wymuszały konieczność oszczędzania tego, co już znalazło się na wyposażeniu żołnierzy. W związku z tym, dowódca pułku mjr Jan Tabaczyński polecił wszystkim dowódcom: „[...] prowadzić największą ekonomię i rzeczywiście troskliwą gospodarkę tak cennymi i niedającymi się łatwo nabyć sortami umundurowania i ekwipunku"9. W praktyce oznaczało to wzmożoną - cotygodniową - kontrolę użytkowania mundurów w trakcie tzw. apeli mundurowych w obecności wszystkich żołnierzy, obserwowanie czy nie niszczą oni mundurów rozmyślnie lub nie wymieniają ich na produkty żywnościowe. Dodatkowo, wpajano im nawyk szanowania posiadanego munduru i dokonywania jego samodzielnych napraw ${ }^{10}$. Ta sytuacja spowodowała, iż oczekiwanymi żołnierzami w szeregach pułku były osoby wykonujące w cywilu zawód krawca i szewca, a ponieważ takich było mało, niektórych podoficerów z kwatermistrzostwa pułku kierowano na odpowiednie kursy, jak np. niejakiego kpr. Gierczyckiego ${ }^{11}$. Ich umiejętności dawały nadzieję na chociaż częściowe rozwiązanie problemów, poprzez naprawę podniszczonych mundurów i obuwia.

Braki w zimowym umundurowaniu były często uzupełniane ubraniami cywilnymi - futrami i kożuchami. Pozyskiwane najczęściej drogą darów, były cennym dodatkiem do posiadanego już ekwipunku - nie tyle $\mathrm{z}$ racji ich wartości materialnej, lecz z uwagi na ciągłe niedostatki w zaopatrzeniu. Należało je chronić i oszczędzać, by w przyszłości mogły służyć innym. Ciepłe i często eleganckie

${ }^{8}$ Ibidem, Rozkaz nr 308 na dzień 12 XI 1919 r. wydany w Landwarowie 11 XI 1919 r., brak paginy.

9 Ibidem, Rozkaz nr 303 na dzień 7 XI 1919 r. wydany Landwarowie 6 XI 1919 r., brak paginy.

${ }^{10}$ Ibidem.

${ }^{11}$ Ibidem, Rozkaz nr 3 na dzień 4 I 1920 r. wydany w Szyrwintach 3 I 1920 r., brak paginy - „Przydzielam przybyłego z kursu krawieckiego kpr. Gierczyckiego do oddz. Konnych Wyw.[iadowców]”. 
futra chroniły wprawdzie od mrozu, ale nie było to jednak odzienie typowo wojskowe. Dlatego efekt takiego przebrania bywał czasem nieco komiczny i odbiegał od przyjętych regulaminów. Wbrew formalnym zakazom żołnierze na własną rękę starali się dopasować otrzymane futra i kożuchy, najczęściej skracając ich długość. Próbowali także przerabiać koce. Wyposażeni w tak niecodzienne stroje chętnie pozowali do zdjęć, które dziś stanowią dowód na ich niełatwą, zimową służbę w tamtym czasie ${ }^{12}$.

Przeróbki były samowolą, sprzeczną z rozkazami dowódców. W rezultacie żołnierzom systematycznie zabraniano tego typu działań, jak również sprzedaży czy wymiany tych szczególnych okryć, np. na prowiant. Racjonalna gospodarka ekwipunkiem przegrywała z potrzebą zabezpieczenia się przed zimnem. Dowódcy batalionów zostali wprawdzie obarczeni obowiązkiem prowadzenia ewidencji i kontroli stanu zachowania umundurowania oraz wszelkiego wyposażenia, za to żołnierze wykazywali się coraz to nowymi pomysłami na rozwiązanie problemu zimowej odzieży. Pod koniec grudnia 1919 r. dowódca pułku wydał rozkaz, w którym w części dotyczącej powyższego problemu, w stanowczym tonie stwierdził:

Przypomina się, że przerabianie koców na mundury jest wzbronione. Winni będą pociągnięci do odpowiedzialności. D-cy oddziałów i pododdziałów mają prowadzić dokładną ewidencję otrzymanego i wydanego ekwipunku i kontrolować czy żołnierze rzeczywiście posiadają ekwipunek w całości i w tej samej ilości. Za zgubione lub zniszczone przez niedbalstwo części ekwipunku należy potrącać żołnierzom z żołdu wartości danego przedmiotu wyekwipowania ${ }^{13}$.

Szybko okazało się, że groźba kary nie była w stanie zatrzymać krawieckich popisów żołnierzy. W zderzeniu między obowiązkiem wykonania rozkazu a potrzebą szybkiego rozwiązania problemu zwyciężyła niesubordynacja. Także dowódcy nie byli skłonni do egzekwowania rozkazów w tej sprawie, o czym świadczą napomnienia, jakie miały miejsce do końca trwania służby na linii demarkacyjnej. W styczniu 1920 r. dowódca pułku pisał, że:

Tegoroczne doświadczenie uczy, że wielu dowódców nie zwraca na to uwagi, skutkiem czego wielka ilość tego drogiego ekwipunku znika, żołnierze sprzedają, posyłają do domów itp. Na wiosnę muszą wszystkie oddziały oddać sorty ekwipunku zimowego w pełnej liczbie. Braki będą przepisane odnośnemu dowódcy do zapłaty ${ }^{14}$.

${ }_{12}$ MTN/Ł, Ikonografia, I-7280, k. 1, 3, 9, 46, 66, Fotografie - Żołnierze II batalionu w Owancie zimą 1919/1920 r.

${ }_{13}$ CAW-WBH, 28 Pułk Piechoty, sygn. I.320.28.5, Rozkaz nr 349 na dzień 26 XII 1919 r. wydany w Szyrwintach 25 XII 1919 r., bez paginy.

${ }^{14}$ Ibidem, Rozkaz na dzień 27 I 1920 r., brak paginy. 
Groźby konsekwencji za niedopilnowanie ekwipunku nie odnosiły zamierzonego skutku, zostały więc zmienione zasady jego rozdziału. W lutym 1920 r., dowódca 28 pSK zdecydował, że z kożuchów przyznanych przez Intendenturę 10 Dywizji Piechoty - jeden otrzyma kancelaria pułku z przeznaczeniem dla kuriera, pozostałe natomiast otrzymają wartownicy i tzw. jezdni (furmani) ${ }^{15}$.

Jeszcze większym problemem było zaopatrzenie w buty. Wobec braku pułkowych warsztatów szewskich oraz zapasów obuwia, stawał się on z każdym dniem coraz poważniejszy. Nic dziwnego, że wymagał chociaż doraźnych rozwiązań, gdyż żołnierze - według opinii dowódcy pułku - nie zawsze potrafili o nie zadbać. Obok apeli o właściwe użytkowanie butów, nikt nie wskazywał żadnych konkretnych rozwiązań w tej sprawie. Była natomiast uwaga, że suszenie mokrego obuwia w bliskiej odległości od ognia, naraża je na szybkie zniszczenie. To spostrzeżenie nie było jednak w stanie wpłynąć na taki sposób suszenia butów przez żołnierzy, gdyż ci chcieli mieć jak najszybciej suche obuwie, umożliwiające wyjście na służbę wartowniczą lub patrolową ${ }^{16}$.

Te z pozoru anegdotyczne wątki dotyczące kożuchów, futer i butów - wskazują, przed jakimi prozaicznymi, ale i istotnymi problemami, stało WP u progu niepodległości, oraz jak ważne było zaspokojenie podstawowych potrzeb i wyposażenia. Nie zawsze było to możliwe i tak stało się na przełomie 1919/1920 r. Mimo to, polska armia - przy niewystarczających środkach finansowych i ciągłych brakach w zaopatrzeniu - toczyła wojnę w obronie ledwo co Odrodzonej Ojczyzny. I ta walka zakończyła się zwycięstwem. W depeszach gratulacyjnych od najwyższych władz wojskowych podkreślany był przede wszystkim hart ducha i determinacja, $\mathrm{z}$ jaką żołnierze pełnili swą służbę.

Nie tylko braki w zaopatrzeniu stanowiły problem. Brak dobrych nawyków w codziennym życiu, troski o ekwipunek oraz surowe warunki służby i egzystencji powodowały, że dla niektórych codzienność na linii demarkacyjnej była zbyt trudna, a pokusa polepszenia sobie bytu na własną rękę zbyt duża, choć ryzykowna. Bezprawne rekwizycje, a czasem też kradzież zwierząt hodowlanych czy drewna, nielegalne wyprawy na tereny litewskie bez zezwolenia, dezercje - to dodatkowe problemy, z którymi musieli zmierzyć się dowódcy. Odbierali skargi od ludności polskiej i litewskiej, natomiast winni popełnianych przestępstw stawali przed sądem. Najbardziej jednak dokuczliwe, obok chorób, było samowolne opuszczanie szeregów. Tej z pozoru spokojnej i bezpiecznej służbie wartowniczo-patrolowej towarzyszyły problemy, wprawdzie prozaiczne, ale mające znaczny wpływ na poziom dyscypliny w szeregach. Były to: niskie temperatury,

\footnotetext{
${ }^{15}$ Ibidem, Rozkaz na dzień 26 II 1920 r. wydany w Kowlu 25 II 1920 r., brak paginy.

${ }^{16}$ Ibidem, 28 Pułk Piechoty, sygn. I.320.28.6, Rozkaz nr 69 na dzień 11 III 1920 r. wydany w Szyrwintach 10 III 1920 r., brak paginy.
} 
niedostateczne zaopatrzenie oraz sposób myślenia i podejścia do obowiązków wielu - nie obytych jeszcze ze służbą wojskową - żołnierzy, nie mających jeszcze świadomości jej celów i znaczenia.

Rozgraniczenie wojsk polskich i litewskich było próbą uspokojenia napiętej sytuacji panującej między Polską a Litwą, lecz trudne sąsiedztwo trwało do 1939 r. Punktem zapalnym było Wilno. Obok roszczeń do miasta, Litwini stawiali Polsce warunek uznania ich niepodległości. Stanowiska nie zmieniali nawet w obliczu zagrożenia bolszewickiego, odrzucając jakąkolwiek możliwość współdziałania z Polską.

Inaczej do współpracy z nią podchodziła Łotwa. Z jednej strony cechowała ją podejrzliwość i obawa przed federacyjnymi planami Józefa Piłsudskiego oraz próby umacniania praw polskiej mniejszości w Łatgalii - lecz z drugiej chęć i potrzeba zacieśnienia wzajemnych kontaktów wobec zagrożenia ze strony bolszewickiej Rosji, przed którą Łotwa nie była w stanie sama się obronić. Nastroje towarzyszące stosunkom polsko-łotewskim często ulegały zmianie. Mimo to, władze łotewskie podjęły starania o podjęcie współpracy z Polską. Jej początkiem było uznanie de facto przez Polskę państwa łotewskiego, co nastąpiło 22 października 1919 r. w Warszawie - w konsekwencji czego, pod koniec tego miesiąca oba państwa nawiązały oficjalne stosunki dyplomatyczne ${ }^{17}$. Także w obliczu zagrożenia bolszewickiego, Łotwa zdecydowała się zawrzeć układ wojskowy z Polską, będąc zainteresowana odrzuceniem Armii Czerwonej jak najdalej od swoich granic. Władze łotewskie poprosiły także o wsparcie militarne w walce o wyzwolenie Łatgalii, okupowanej przez wspomnianą armię. Rozmowy w tej sprawie rozpoczęły się 17 września 1919 r. w Wilnie. W składzie trzyosobowej delegacji łotewskiej znaleźli się przedstawiciele rządu do spraw politycznych, ekonomicznych i wojskowych. Stronę polską reprezentowali Leon Wasilewski (były minister spraw zagranicznych RP) ${ }^{18}$, rtm. Prus-Bogusławski i pchor. Puchalski (imion nie ustalono). W skład trzyosobowej delegacji łotewskiej weszli natomiast: Karlis Žarins (sprawy polityczne, ekonomiczne i wojskowe), Karlis Spade (sprawy ekonomiczne) i kpt. Oskar Asmanis (sprawy wojskowe) ${ }^{19}$. W trakcie kilku spotkań omówiono najważniejsze sprawy dotyczące planowanej operacji. Strona łotewska była $\mathrm{w}$ stanie wystawić trzy dywizje piechoty, jedną baterię artylerii oraz jeden pociąg pancerny. Siły te były słabo wyposażone w broń i w niezbędną amunicję.

\footnotetext{
${ }_{17}$ P. Łossowski, Łotwa nasz sąsiad. Stosunki polsko-łotewskie w latach 1918-1939, Warszawa 1990, s. 9-11.

${ }_{18}$ Leon Wasilewski był ministrem spraw zagranicznych RP w okresie 17 XI 1918 - 16 I 1919.

${ }_{19}$ Archiwum Akt Nowych (dalej: AAN), Akta Leona Wasilewskiego, sygn. 41, Raport z narady delegacji polskiej i łotewskiej odbytej 17 IX 1919 roku w Wilnie, brak paginy; Ë. JĒKABsons, Początek stosunków Łotwy i Polski: pierwsze kontakty, wiosna-jesień 1919 roku, „Res Historica” 2016, nr 42 , s. 260.
} 
W praktyce, nikła wartość bojowa armii łotewskiej oznaczała, że cały ciężar operacji spoczywać będzie na WP. W tym celu została sformowana Grupa Operacyjna pod dowództwem gen. Edwarda Rydza-Śmigłego w składzie 1 i 3 Dywizji Piechoty Legionów ${ }^{20}$. Celem działań połączonych sił polsko-łotewskich było wyparcie wojsk bolszewickich z Łatgalii oraz opanowanie Dyneburga. W trakcie rozmów $\mathrm{z}$ delegacją łotewską, strona polska zastrzegła, że w przypadku zajęcia twierdzy przekaże ją Łotyszom, ale zachowa prawo do korzystania z niej dla swych potrzeb wojskowych ${ }^{21}$. Celem politycznym operacji było: „[...] nawiązanie bezpośredniej łączności Polski z Łotwą i osiągnięcie przez to wpływów do przyszłego ukształtowania się sojuszu Polski z państwami nadbałtyckimi”"22. Dnia 30 grudnia 1919 r. podpisana została umowa między Naczelnym Dowództwem WP, a dowództwem wojsk łotewskich, zawierająca m.in. zapis o ustanowieniu wspólnego dowództwa, które sprawować miał gen. E. Rydz-Śmigły ${ }^{23}$.

Operacja zimowa na Łotwie, której nadano kryptonim „Zima”, rozpoczęła się 3 stycznia 1920 r. Śnieg, kilkudziesięciostopniowe mrozy i marsze przez śnieżne zaspy - poważnie utrudniały sprawne wykonywanie rozkazów i realizację celów operacji. Warunki, jakie czekały żołnierzy polskich na Łotwie, przedstawił jeden z uczestników tej operacji, Gustaw Łowczowski:

Terenem przyszłych działań miały być dawne polskie Inflanty. Zachodnia ich część jest płaska, część południowo-wschodnią stanowią faliste wzniesienia. Pełno tu jezior tworzących miejscami łańcuchy. Gdy nie są zamarznięte, stanowią poważne przeszkody. Działania zaczepne utrudnia duża ilość lasów. Zimą dodatkową przeszkodą jest surowy klimat, mrozy dochodzące do 40 stopni i śniegi, których warstwa dochodzi do metra, a zamarznięte z wierzchu stanowią w natarciu gorszą przeszkodę niż druty kolczaste i utrudniają przemarsze. Klimat ogranicza więc zimą walkę do miejscowości, gdyż piechota podczas mrozu nie może leżeć na śniegu więcej niż godzinę $e^{24}$.

Operacja zimowa na Łotwie zapisała się na trwałe w pamięci jej uczestników, którzy długo jeszcze wspominali warunki terenowe i atmosferyczne, $\mathrm{z}$ jakimi przyszło im się zmierzyć. Stałym elementem wspomnień były ciężkie marsze drogami głęboko zasypanymi śniegiem czy kłopoty z budową stanowisk bojowych, jak np. okopanie się w polu, co było na ogół niewykonalne z uwagi na

${ }^{20}$ A. Borkiewicz, Dzieje 1-go pułku piechoty Legionów. Lata wojny polsko-rosyjskiej 1918-1920, Warszawa 1929, s. 347-348.

${ }^{21}$ AAN, Akta Leona Wasilewskiego, sygn. 41, Raport z narady delegacji polskiej i łotewskiej odbytej 17 IX 1919 roku w Wilnie, brak paginy.

${ }^{22}$ Cyt. za: A. Borkiewicz, op. cit., s. 348.

${ }_{23}$ Dokumenty i materiały do historii stosunków polsko-radzieckich, t. II, Listopad 1918 - kwiecień 1920, Warszawa 1961, s. 521-522.

${ }^{24}$ Cyt. za: G. Łowczowski, Piąty pułk piechoty Legionów „Zuchowatych”, Londyn 1968, s. 107. 
zamarzniętą ziemię. Możliwość taką dawało dopiero wykorzystanie materiałów wybuchowych. Mróz i śnieg wymuszały na dowódcach decyzje, które nie tylko wpływały na większą skuteczność działań, ale przede wszystkim chroniły żołnierzy przed skutkami niskich temperatur. Jednym ze sposobów było wystawienie przez plutony na obsadzanych odcinkach kilkuosobowych czujek. Dzięki temu, reszta pododdziału mogła w tym czasie przebywać na improwizowanych kwaterach, gotowa w każdej chwili do zajęcia wyznaczonych stanowisk ogniowych. $\mathrm{Na}$ każdym z nich znajdował się też - odpowiednio przygotowany - posterunek $\mathrm{z}$ karabinem maszynowym ${ }^{25}$.

Mimo podejmowanych wysiłków, przypadki odmrożeń nie były czymś wyjątkowym. Doświadczali tego także oficerowie, najczęściej przeceniający swą odporność na niskie temperatury. Tak było w przypadku por. Wilhelma Wilczyńskiego z 5 Pułku Piechoty Legionów, który tak wspominał swoje pierwsze chwile po przybyciu na Łotwę:

Zaraz po wyładowaniu wojska i taboru formujemy kolumnę marszową i brniemy po śniegu w kierunku frontu. Nastaje zmierzch i droga wśród ciemności staje się ciężka i męcząca. W dodatku ostry zimny wiatr wieje od strony północnej znad Dźwiny. Czuję jak marznie mi lewe ucho, które jest nastawione na wiatr wiejący z boku. Po chwili ucho szczypie mnie uczciwie, ale nie chcę zamienić maciejówki na furażerkę, którą lepiej mogłem to ucho przed zimnem zabezpieczyć. Przecież jestem żołnierzem i to $\mathrm{w}$ dodatku zaprawionym do trudów i wytrzymałym na chłody i zimna. Istotnie szczypanie ucha, a odmrożone już utraciło czucie, co mnie nieuświadomionego jeszcze utwierdzało w tym przekonaniu, że żołnierzowi tak przywykłemu do mrozów stać się nic nie może. Ponieważ w dodatku było ciemno, nikt nie mógł stwierdzić okiem, ze ucho jest białe i odmrożone i przez to samo zwrócić mi uwagę $e^{26}$.

Oficer ten opisał w swych wspomnieniach wiele innych problemów utrudniających służbę polskim żołnierzom $w$ tak ekstremalnych warunkach atmosferycznych. Zawiane śniegiem drogi, zaspy śnieżne i mróz były codziennością dla wojska, które prawie każdego dnia znajdowało się w drodze. Wąskie, wydeptane ścieżki opóźniały marsze, które możliwe były na ogół pojedynczo, jeden żołnierz za drugim, często także zapadali się po pas w głębokim śniegu ${ }^{27}$.

Mimo złych warunków atmosferycznych, utrzymanie dróg w stanie umożliwiającym przejazd lub przejście żołnierzy - było niezbędne dla przegrupowywanie oddziałów wojskowych. Niektórzy dowódcy zlecali nawet żołnierzom pełniącym obowiązki gońców oczyszczanie dróg ze śniegu przy pomocy ludności

25 Vide: O granice Drugiej Rzeczypospolitej. Frontowe wspomnienia Wilhelma Wilczyńskiego, wstęp i oprac. A. JęDRZEJEWSKA, P. WAINGERTNER, Łódź 2012, s. 120.

${ }^{26}$ Ibidem, s. 93.

${ }^{27}$ Ibidem, s. 111, 122. 
cywilnej ${ }^{28}$. Nie wszędzie jednak było to możliwe, gdyż prace te utrudniały częste zamiecie śnieżne i silny wiatr. W tych warunkach, transportowanie sprzętu i prowiantu stanowiło nie lada wyzwanie, które wymagało od ludzi i zwierząt wielkiego wysiłku. Jak wspominał W. Wilczyński:

Wiele kłopotu mam z dowożeniem żywności dla kompanii. Konie zapadające się $\mathrm{w}$ śniegu po brzuchy i ciągnące jeszcze $\mathrm{w}$ dodatku sanie załadowane chlebem, mięsem itd. męczą się strasznie. Dziwię się, że jeszcze nie zdychają, bo wyglądają na strasznie zmarnowane. W każdym razie, gdy wyjadą rano wczas, to wracają wieczorem, a przecież do Szynszczyna, gdzie jest pobranie żywności, jest tylko osiem kilometrów ${ }^{29}$.

Konie były nie tylko zmęczone ciężką służbą w tych trudnych warunkach, lecz narażone były w nich na różnego rodzaju choroby, co stanowiło dodatkowy problem z utrzymaniem ich kondycji - wymagały wówczas leczenie przez wojskową służbę weterynaryjną, co w warunkach frontowych nie było łatwe. Podobnie jak ludzi, należało również chronić przed mrozem konie, umieszczając je w zadaszonych pomieszczeniach (prawdopodobnie w nich ulegały zarażeniu chorobami) ${ }^{30}$.

Opóźnienia w transporcie prowiantu można było uzupełnić żywnością nabywaną od miejscowej ludności. Mimo życzliwości, z jaką spotykali się polscy żołnierze, nie zawsze było to dobre i bezpieczne rozwiązanie. Na terenach, przez które przechodziły polskie oddziały zdarzały się przypadki tyfusu, który był równie dużym problemem dla wojska, co skutki niskich temperatur. Dlatego, by chronić żołnierzy - wielu dowódców zabraniało zakupu artykułów żywnościowych od mieszkańców wsi oraz picia wody. Konieczne stało się też omijanie zainfekowanych domów. Mimo tych zakazów, przypadki tyfusu w szeregach były dość liczne.

W połowie lutego $1920 \mathrm{r}$. oddziały polskie weszły do Dyneburga. Na skutek lekkiej odwilży wkraczające oddziały maszerowały po brukowanych ulicach, po których można się było poruszać z większą swobodą niż przez zasypane śniegiem drogi. Była to $\mathrm{z}$ pewnością duża ulga po trudnej kampanii. W takich to - dogodniejszych dla żołnierzy warunkach - odbyła się 15 lutego defilada przed gen. E. Rydzem-Śmigłym i przedstawicielami wojsk łotewskich. Jednak codzienna służba garnizonowa, którą żołnierze pełnili od chwili wkroczenia do miasta, nadal była trudna, a warunki bytowe przysparzały kłopotów dowództwu. Kwatery

${ }^{28}$ A. Borkiewicz, op. cit., s. 414.

${ }^{29}$ O granice Drugiej Rzeczypospolitej..., s. 129.

30 „W czasie ofensywy dźwińskiej wszystkie moje konie, kwaterując po brudnych stajniach i szopach, nabawiły się świerzbu. Świerzb ten, zawleczony został przez bolszewików, którzy wstawiając swe konie do stajen i różnych szop, pozarażali nimi wszystkie budynki gospodarcze. Ze względu na silne mrozy, częstokroć zmuszeni byliśmy dla swoich koni szukać schronienia i dlatego wstawiać je do stajenni szop. W ten sposób, początkowo nawet nie wiedząc, pozarażaliśmy je świerzbem" - cyt za: O granice Drugiej Rzeczypospolitej..., s. 135. 
były zazwyczaj pełne brudu, przez co w wielu oddziałach szerzył się tyfus, który zbierał śmiertelne żniwo wśród żołnierzy. Jak na ironię, wielu z tych, co przeżyło w polu, zapadło na wspomnianą chorobę w dopiero w Dyneburgu. Najwięcej ofiar było oddziałów zakwaterowanych w samym mieście, co potwierdził w swych wspomnieniach W. Wilczyński:

Ze szpitala co dzień wywozi się po kilku zmarłych na tyfus żołnierzy i grzebie na cmentarzu wojskowym we wspólnych grobach żołnierskich. Wielu więc tych, których na polu walki oszczędzały kule, zagarniała epidemia tyfusu i składała z nich swoją ofiarę nieubłaganej śmierci ${ }^{31}$.

Postój w Dyneburgu, który trwał do końca marca 1920 r., przeznaczony był na leczenie ludzi i koni. Po kilku dniach odpoczynku, rozpoczęły się normalne zajęcia, jak ćwiczenia poddziałów, wykłady i nauka dla analfabetów. Był to także czas pierwszych podsumowań kampanii zimowej. Na przebieg działań niewątpliwie wpływ miały trudne warunki atmosferyczne: śnieg i niskie temperatury. Te dwa czynniki zmieniły sposób prowadzenia walki i przemieszczania się wojsk. Wąskie, wydeptane ścieżki nie pozwalały na marsz ubezpieczony, a tym bardziej na rozwinięcie tyraliery. Żołnierze brnęli w śniegu, ciągnąc na sankach karabiny maszynowe, które często - na skutek mrozu - po prostu nie działały. Słabą stroną kampanii była też łączność prowadzona głównie za pośrednictwem gońców. Żołnierze wyznaczeni do tej roli przewozili meldunki konno, korzystali z sań lub przemieszali się pieszo. $\mathrm{W}$ tak skrajnych warunkach, dużym problemem był transport rannych na tyły, który średnio trwał dwa dni. Przy niskich temperaturach, bez zmiany opatrunków i ciepłego jedzenia - wielu z nich nie otrzymało pomocy na czas i umierało $\mathrm{w}$ drodze ${ }^{32}$.

Operacja „Zima” była kampanią wyjątkową i wyczerpującą, w której niemożliwe wręcz stawało się działania według przyjętych reguł i wymagało szybkich decyzji dostosowanych do panujących warunków terenowych i pogodowych. Natomiast siłą tej operacji byli żołnierze, ich determinacja, poczucie dyscypliny i wola przetrwania w tak niesprzyjającej aurze. W wyniku podjętej akcji zbrojnej, oddziały polskie i łotewskie pod wspólnym dowództwem gen. E. Rydza-Śmigłego wyparły wojska bolszewickie z Łatgalii. Jednak cel polityczny, do jakiego dążyła Polska, nie został do końca osiągnięty. Także wspomniana wcześniej zmienność Łotwy w stosunku do niedawnego sojusznika dała znać o sobie. Mimo pomocy ze strony Polski, Łotwa realizowała własne cele. Przede wszystkim dążyła do zakończenia walk, oczyszczenia jej terytorium z sił wroga przez polskie oddziały i ułożenia sobie stosunków z Rosją. Polska natomiast chciała rozwinąć współpracę

\footnotetext{
31 Ibidem, s. 137.

32 A. Borkiewicz, op. cit., s. 468-472.
} 
wojskową z Łotwą i miała nadzieję na wsparcie ze strony oddziałów łotewskich $\mathrm{w}$ walce $\mathrm{z}$ bolszewikami. Zgodnie z wcześniejszą zapowiedzią, Polacy pozostawili swój garnizon w twierdzy w Dyneburgu i wycofali się z Łatgalii.

Przed rozpoczęciem operacji „Zima”, gen. E. Rydz-Śmigły, dowódca Grupy Operacyjnej, zwrócił się do swych żołnierzy m.in. w następujących słowach:

Dywizje legionowe mogą tylko zwyciężać. Bolszewicy jeszcze raz przekonają się, że każdy atak polski musi mieć powodzenie, sprzymierzeńcy nasi Łotysze muszą w Was, jako przedstawicielach Armii Polskiej, poznać żołnierzy pełnych poczucia honoru, rycerskich, karnych, strasznych dla wroga, ludzkich i sprawiedliwych dla przyjaciół. Pamiętajcie, że podług Was będą oni sądzić całą Armię Polską 33 .

Zgodnie z życzeniem dowódcy grupy, żołnierze wykonali swoje zadanie. Również Polska wywiązała się z umowy zawartej z Łotwą 30 grudnia 1919 r., ale zapłaciła za to ogromną cenę. Miarą zaangażowania oddziałów polskich w tę operację były poniesione straty w ludziach. W poszczególnych pułkach kształtowały się różnie, ale były wysokie. Obok zabitych i rannych, zanotowano dużą liczbę żołnierzy, którzy doznali poważnych odmrożeń. W samym 1 Pułku Piechoty Legionów było ich $763^{34}$. Były także przypadki zapalenia płuc, tyfusu i innych chorób, na które zapadło 230 żołnierzy $y^{35}$.

Dwie opisane w artykule „misje” polskich oddziałów w latach 1919-1920 różniły się od siebie zakresem działań, stopniem trudności i skalą niebezpieczeństwa. Ich cechą wspólną była natomiast zima i towarzyszące jej niedogodności - śnieg, niskie temperatury, czasem niedostateczne wyposażenie na wypadek mrozów, a w konsekwencji choroby i urazy. Wyjątkowo trudna służba przypadła żołnierzom na Łotwie, gdzie obok zagrożenia życia w starciu z wrogiem, musieli zmagać się każdego dnia $z$ długimi nieraz marszami przez śnieżne zaspy, transportując w tych trudnych warunkach sprzęt niezbędny do walki. W przeciwieństwie do żołnierzy ochraniających linię demarkacyjną na Litwie, uczestnicy operacji zimowej na Łotwie nie cierpieli aż tak wielkiego niedostatku w postaci braków zimowego ekwipunku. Sądzić zatem należy, że ta wyprawa była lepiej przygotowana, chociaż możliwości WP w zaspokajaniu niezbędnych potrzeb życiowych były w tym czasie wciąż nie najlepsze. Dla wszystkich żołnierzy, zarówno pełniących z pozoru bezpieczną służbę na Litwie, jak i dla tych, którzy z narażeniem życia walczyli na Łotwie, był to czas próby ich charakteru, wytrzymałości i odporności na trudy służby, którą wypełniali w tak skrajnych i dokuczliwych warunkach atmosferycznych, jakie stwarza zima.

\footnotetext{
${ }^{33}$ Cyt. za: G. Łowczowski, op. cit., s. 108.

34 S. Pomarański, Zarys historii wojennej 1-go pułku piechoty Legionów, Warszawa 1931, s. 63.

35 A. BORKIEwICZ, op. cit., s. 472.
} 


\section{Agnieszka Jędrzejewska}

\section{WINTER SERVICE OF SOLDIERS OF THE POLISH ARMY IN LITHUANIA AND LATVIA AT THE TURN OF 1919/1920}

Summary: Winter is not the best time for miltary operations. It is necessary when political situation or international agreements are contained. In 1919 and 1920 Polish Army has served in Lithuania and Latvia in winter time. In Lithuania the soldiers have practiced patrol and garrison duty on polish-lithuanian border. In the same time other polish units have taken part in military operation in Latvia. There were the common features of these mission: winter, snow, low temperatures. In these circumstances the duty was much difficult. What else, the soldiers have fallen ill like cold and frost-bites.

Keywords: Polish Army, Lithuania, Latvia, military operation, the border, winter. 